\title{
OTU Domain-Containing Protein 5
}

National Cancer Institute

\section{Source}

National Cancer Institute. OT U Domain-Containing Protein 5. NCI Thesaurus. Code C124954.

OTU domain-containing protein $5(571 \mathrm{aa}, \sim 61 \mathrm{kDa})$ is encoded by the human OT UD5 gene. This protein plays a role in protein deubiquitination that modulates inate immunity. 